Geopolítica(s) Revista de estudios sobre espacio y poder ISSN: 2172-3958

https://dx.doi.org/10.5209/geop.69018

\title{
American "Populism" and the Spatial Contradictions of US Government in the Time of COVID-19
}

John Agnew ${ }^{1}$

Recibido: 16 de abril de 2020 / Aceptado: 10 de mayo de 2020

\begin{abstract}
President Donald Trump has been the public face of the blundering managerial response of the US federal government to the Coronavirus/COVID-19 pandemic. Yet, beyond Trump's personal failure lies a failure of the US governmental system. More specifically, the role of the federal government in fashioning nationwide policies across a range of areas, including public health, that one think would be empowered by a self-defined "nationalist" or right-wing populist in the White House, has been crippled by an anti-federalist ideology and the institutional inertia it has created. These have roots going back to the 1980s and the distortion of historic US federalism that these have entailed.
\end{abstract}

Keywords: COVID-19 pandemic; United States; Donald Trump; right-wing populism; public health policy.

\section{[es] El "populismo" americano y las contradicciones espaciales del gobierno de Estados Unidos en tiempos de COVID-19}

Resumen. El presidente Donald Trump ha sido el rostro público de la torpe respuesta gerencial del gobierno federal de los Estados Unidos a la pandemia de Coronavirus/COVID-19. Sin embargo, más allá del fracaso personal de Trump se encuentra un fracaso del sistema gubernamental de los EE UU Más específicamente, el papel del gobierno federal en la formulación de políticas a nivel nacional en una variedad de áreas, incluida la salud pública, que uno cree que sería potenciado por un ocupante de la Casa Blanca que se ha autodenominado "nacionalista" o populista de derecha, se ha paralizado por una ideología antifederalista y la inercia institucional que ésta ha creado. Estos hechos tienen raíces que se remontan a la década de 1980 y la distorsión del federalismo histórico de los EE UU.

Palabras clave: pandemia de COVID-19; Estados Unidos; Donald Trump; populismo de derecha; política de salud pública.

\section{[pt] O "populismo" americano e as contradições espaciais do governo dos Estados Unidos em tempos de COVID-19}

Resumo. O presidente Donald Trump tem sido o rosto público da resposta gerencial do governo federal dos EUA à pandemia do Coronavírus/COVID-19. No entanto, além do fracasso pessoal de

1 Distinguished Professor of Geography, University of California, Los Angeles, Estados Unidos.

E-mail: jagnew@geog.ucla.edu 
Trump, existe um fracasso do sistema governamental dos EUA. Mais especificamente, o papel do governo federal na formulação de políticas nacionais em uma variedade de áreas, incluindo a saúde pública, que deveriam ser supostamente potenciadas por um ocupante da Casa Branca autodenominado como "nacionalista" ou populista de direita auto-definido na Casa Branca, foi prejudicado por uma ideologia anti-federalista e pela inércia institucional que criou. Este processo tem raízes que remontam à década de 1980 e a distorção do federalismo histórico dos EUA.

Palavras-chave: pandemia da COVID-19; Estados Unidos; Donald Trump; populismo de direita; política de saúde pública.

Sumario. Introduction. 1. Trump and National-Populism. 2. Populism and the National. 3. The Retreat of the Federal Government since the 1980s. 4. The Spatial Paradox of Trump's "Populism" and the COVID-19 Pandemic. References.

Cómo citar: Agnew, J. (2020). American "Populism" and the Spatial Contradictions of US Government in the Time of COVID-19. Geopolitica(s). Revista de estudios sobre espacio y poder, 11(Especial), 15-23.

\section{Introduction}

Pandemics are by definition global in character and spread from place to place through travel and community spread. They are a test for different governmental systems and the geopolitical arrangements upon which they rest. Absent much in the way of effective global governance, national governments typically have the best resources and expertise to limit spread and manage healthcare as the disease spreads across their territories. Simply leaving management to lower tiers of government can create major problems when they adopt different testing and mitigation strategies and do not have adequate resources and expertise to institute them.

In the United States there has been much controversy over the problematic role of the federal government in the current COVID-19 pandemic. The lack of any national plan for dealing with the pandemic has been particularly obvious from the outset (e.g. Haffajee and Mello, 2020). Much of the critique has focused on the lackluster performance of President Donald Trump; from his months-long dismissal of the dangers posed by the pandemic to his chaotic administrative approach to the challenges posed by the spread of the virus. Trump has certainly been more part of the problem than any sort of cure. But the pandemic exposes rather deeper structural flaws in the US system of government than just the psychological and intellectual flaws displayed by the person who has just happened to occupy the office of President at this trying time.

More specifically, there is a fundamental contradiction between a President like Trump elected on a national-populist basis and the reality of a national-level governmental system that since the 1980s has been increasingly anti-federalist in its legislative and executive preferences for privatization and "small government" and thus immune to any sort of forward-looking role for the federal government in domestic policy. The manifest federal-government failures in managing the COVID-19 pandemic in the US are the outcome of this contradiction. 


\section{Trump and National-Populism}

Trump campaigned for the US presidency in 2016, unlike previous Republican candidates for that office, on an openly populist platform (Agnew and Shin, 2019). His central claim, emblazoned on the baseball hats of his supporters, was "To Make America Great Again." Following on a two-term first-time AfricanAmerican President, whom Trump had personally insulted and run down from before the 2008 election including being the primary source of the charge that Obama was an illegitimate president because he had not been born in the US, this slogan was not hard to decode. Indeed, since his election much of what Trump has done has been to undo what Obama had done with respect of social, healthcare and environmental regulation. Apart from that, Trump has followed recent Republican orthodoxy on slashing the federal income tax on high-payers and appointing ultraconservative judges to the federal courts. In the election campaign, however, more than these initiatives, Trump emphasized "toughness" in "bringing back" jobs in manufacturing that had somehow been stolen by "China" (not a word about the role of US multinational businesses in this) and building a wall with Mexico (that Mexico would pay for) to keep out the "illegals" that he spent much energy on the campaign trail decrying for their criminality and threat to the racial composition of the country. The entire thrust of Trump's public persona has been to present himself as a national savior with a very clear sense that those he desires to see exalted after the Obama years is the largely elderly white demographic that he appealed to support him in 2016. Since arriving in office he has made no attempt to portray himself as a president of the entire country only of those who display loyalty to him (Wehner, 2020).

Attacking the "mainstream media" (particularly so-called quality newspapers and television news that report in a fact-driven rather than ideological way) has played a vital part in establishing Trump in his prophetic role as leader. The media must be discredited to undermine the empirical truth in which they claim to trade. Steve Bannon, Trump's house theoretician, insisted that the imperative is to dominate the conversation, not to engage in a battle of ideas: "The Democrats don't matter," he says. "The real opposition is the media, and the way to deal with them is to flood the zone with shit" (quoted in Thornhill, 2018). Trump has thus appealed to a cultural vein in American society that is suspicious of specialist knowledge and the notion of objective truth. His most important stock-in-trade is to accuse all and sundry who are not loyal to the lies and fabrications he espouses of trading in "fake news." This is how he appeals above all to "his people" or "base."

Say what you will about him, but Trump has been a political genius in managing to conquer a Republican Party that initially was allergic to his appeal, particularly on economic issues such as trade barriers, and in his consistently receiving since his election support in opinion polls of around $80 \%$ percent or so of selfidentified Republicans polled through March 2020. Even in the face of a dreadful record of mismanaging the early warnings of the coronavirus pandemic, Trump still retained significant popular support (Gabriel and Lerer, 2020). His reservoir of support among Republican Party voters is based on a "fealty, a visceral and emotional attachment" that is still triggered by his open displays of nativism and attachment to a nostalgic vision of an America that had been "lost" (quoted in Waldmeir, 2020). Indeed, in parts of rural/small town America, his supporters are 
already prepared to blame their globalist co-nationals who travel abroad for the virus coming into their America (Kilgore, 2020). That he rhetorically has continued by and large to demonize his political opponents and rewrite his own history in relation to the pandemic shows how much he has not changed operationally even as the challenges he faces are no longer those of his own invention, like the Ukraine imbroglio that led to his impeachment, but something that would test even the best of leaders (e.g. Baker, 2020; Bump, 2020; Parker and Rucker, 2020).

Even in the face of the most significant challenge facing a US president in a generation he has remained focused on his re-election in November 2020 rather than dealing with the crisis at hand. Populism always seems to privilege campaigning over governing, not least because its main tenets, beyond claiming "the people" as its leitmotif, are riling up anger and resentments rather than pursuing rational policy goals or good governance per se (Agnew and Shin, 2019). Trump's abject performance in a prime-time speech about the pandemic on 11 March 2020 as he struck a "starkly militaristic and nationalistic tone" while the country was being radically upended by what he termed a "foreign virus," as if it were not already abroad in the land, was widely panned by critics (Glasser, 2020). But it probably resonated positively with those he wishes to mobilize for November. They know that foreigners are always to blame, even as their favorite son was off playing golf at one of his own resorts and rallying his base in rambling soliloquys rather than preparing administratively for the pandemic no longer just on the horizon.

\section{Populism and the National}

Key to the entire geopolitical framing that brought Trump to the White House has been the discursive opposition between globalism (and globalists) on the one hand and nationalists favoring the people and its national state on the other. The fusion of an idealized people with the national state is by no means alien to American political development (Peel, 2017). This framing was the one suggested by Steve Bannon in which rather than pitching himself as the agent of Wall Street and as a business-as-usual Republican, the only way Trump could win in 2016 was in bringing into national electoral politics people alienated from both of the dominant parties by the lackluster performance of the US domestic manufacturing sector and slumping median household incomes since the 1990s. In turn, the only way to do this was to criticize the liberal global order and talk about re-establishing a territorial sovereignty over borders and the economy that had been lost with the latest round of globalization since the 1980s. Imposing tariffs and opposing international trade agreements were the main strategies used to pursue these goals, even as the tax cuts widened the federal government fiscal deficit that could only be financed by foreign sales of US treasury bonds. The Republican obsession with the federal deficit simply disappeared overnight.

At the same time, of course, Trump was himself very clearly a globalizer with his foreign investments in hotels and golf courses. His cover on this was to paint himself as an American everyman down to how he spoke and what he ate. This is a typical move on the part of right-wing populists. His business "successes" therefore (notwithstanding a long history of bankruptcies and questionable loans) could be viewed as evidence of his managerial intelligence even as he had to overcome the 
disability of being just another everyman. As a neo-patrimonial figure dispensing favors to his subjects/people, Trump would reward his supporters through punishing foreign interests and by channeling federal resources and tax-favored capitalist investment to their benighted communities (Riley, 2017). This self-presentation met with enormous success among a significant portion of the electorate concentrated largely in southern and western states but with enough strength in what turned out to be the crucial states (given the indirect nature of US presidential elections through the Electoral College) of Michigan, Pennsylvania, and Wisconsin to give him a victory even as he failed to achieve a majority of the national vote. As a caveat, I should note that both he and his opponent, Hillary Clinton, had the largest negative approval ratings of any presidential candidates since polls had asked the question (Agnew and Shin, 2019).

The claim to a national people as the primary constituency, even though we know that Trump supporters tend to be a very specific demographic-cultural grouping, is central to the entire populist rationale. In the US case this rests first and foremost on ideas about the founding groups and their racial-ethnic profiles. These, of course, are people of primarily Western European ancestry like Trump himself. When Trump first declared his presidential candidacy, as he descended the escalator in monarchical fashion at Trump Tower in New York City in 2015, he made his case centrally by declaring what he was against, in the case at hand, Mexican immigrants crossing the southern border of the US and defiling the national space by their very presence, to which his answer would be to build a wall and otherwise close off the United States from the rest of the world as best he could. This was Trump's national-populist promise.

\section{The Retreat of the Federal Government since the 1980s}

While representing "his" people, presumably a national constituency at least in theory, Trump has also been heir to a set of ideological positions that have been to a considerable extent contradictory to his national-populist claim. These were apparent in his 2016 campaign but have become glaringly obvious in the years in office. Certainly, hostility to professional expertise and science and disdain for disinterested journalism are often fundamental components of right-wing populism (e.g. Gerson, 2020). But in the contemporary United States they are frequently connected popularly to government. President Ronald Reagan famously announced in his inaugural address as President of the United States that "Government is not the solution to our problem, government is the problem." Reagan did not so much have professional expertise in mind. But he certainly wished to trim and limit the role of the federal government. He opened the door to doubts about the very idea of the "public interest" and disinterested pursuit of objective knowledge.

The very term Federalist was redefined to mean the exact opposite of what it meant to the writers of the US Constitution (e.g. Agnew, 2005, pp.102-18; Edling, 2003). Thus the right-wing Federalist Society is in fact largely anti-federalist in orientation, belittling the roles of the federal government that Madison and Hamilton had championed (see, e.g., Ketcham, 1986). Trump has picked up on this truly anti-federalist viewpoint in his attacks on the purpose and expertise of the federal government tout court and in relation to the experts in government agencies such as 
the EPA, the Department of the Interior, the State Department, the FBI and the Department of Justice, and the Department of Defense. Shrinking the role of the federal government thus fulfilled the view that markets were always better than government and that there is no such thing as the public interest (e.g. Frank, 2008; Brown, 2019).

The Reagan years marked the beginning of what has been called the neoliberal assault on the role of the federal government in managing the US economy and providing for the expansion and protection of fundamental civil rights. From the neoliberal perspective, the best government is that which does least except insofar as it favors privatized solutions and capitalist interests over public institutions. In practice this was to declare an open season "to strip-mine public assets for the benefit of private interests" (Packer, 2020). It was an organized reaction against the socalled liberal-Keynesian view that governments should use fiscal policy, government spending and tax increases, to stimulate demand during economic downturns. In its place neo-liberalism variously encouraged monetary as opposed to fiscal policy and tax cuts, particularly on the wealthy and business, as supply-side stimulus. It also preferred private to public provision even of goods, such as healthcare, that most people might reasonably regard as better made available on a public basis. Trump has certainly governed in this neoliberal vein (Packer, 2020).

At the same time, Trump has inherited and cultivated the anti-federalist vote that came out of the civil rights struggles of the 1960s and led to the Republican strategy since Richard Nixon of hunting for white voters in the US South (Maxwell and Shields, 2019). From this viewpoint, the federal government represents both the hated "Union" that won the civil war and the imposition on the South of norms and regulations that do not fit their "heritage." This heritage, as Maxwell and Shields (2019) brilliantly deconstruct, consists of an amalgam of white racism, patriarchy, and religious zealotry used to justify the other two. In this construction, the "Deep State" to which Trump frequently refers, typically associated with rightwing conspiracy theories, is not the bugaboo that libertarians might associate with limiting access to certain calibers of guns or imposing vaccinations, although these can be present too, but more the sense of a national-level government that imposes rules such as affirmative action, restricts local law enforcement, and insists on the basic equality of all citizens in the eyes of the law. With more than a nod to a confederate imaginary of the United States, Reagan in his day often used the locution "these" United States to emphasize the sovereignty of the states against that of the federal government.

Trump's recourse to the rhetoric of culture war over abortion, gay rights, immigrant undermining of American "culture" and so on all are designed to appeal to a constituency that sees the federal government (particularly the judiciary) as useful only in the negative sense of restricting its enforcement powers in the jurisdictions where they live rather in terms of an affirmative role in providing goods and services on an equal basis nationwide.

The net effect of these two trends towards an anti-federalist conception of the federal government has been to produce an increasingly paralyzed and ineffective national government apparatus. This has been on full display in the first four months of 2020 in relation to the crisis spawned by the spread of COVID-19. 


\section{The Spatial Paradox of Trump's "Populism" and the COVID-19 Pandemic}

So, at the same time Trump appeals to a conception of a tightly walled and contained national-territorial homeland he is also heir to a weakened federal government that is the outcome of years of systematic degradation at the hands of antifederalists of several types. On the first count there have been the years of systematic underfunding of national agencies devoted to health and welfare. This reflects a bias against public funding (and federal taxation) and a preference for private initiatives with limited regulatory controls. On the second count there has been a trend to leave all sorts of issues, such as health care finance and provision, entirely to the states and localities. This reflects the view of the federal government as a usurper of local "heritage" and traditions and dangerous enforcer of equal citizenship and rights. It is not so much that a case cannot be made for effective local and regional democracy but that the federal role as a coordinator and manager has been systematically sidelined because of an anti-federalist ideology that has completely vitiated Trump's claim to represent an idealized national-people walled off from the rest of the world.

Trump has himself weakened the federal government in very specific ways since arriving in office in 2017, not least in relation to public health management. Trump's neo-patrimonial promises referred to previously as important to his 2016 campaign for President have been largely forgotten. The promised investments in national infrastructure and in replanting manufacturing industry have come to nothing. Will these finally matter when he is up for re-election? Perhaps not, but more importantly he has made numerous promises to address the COVID-19 crisis practically rather than just rhetorically but without much delivery that may well come back to haunt him in November 2020 (Drezner, 2020). His main achievements in office have been a giant income tax cut for the wealthy and business in 2017 and the appointment of numerous ultra-conservative judges to the federal courts. Period. Even as he has continued with his populist-nationalist rhetoric, Trump has systematically degraded the functioning of the US federal government (e.g. Bergen, 2019; Rucker and Leonnig, 2020). Almost every other government department has either no or acting leadership. Many of the political appointees running their agencies are utterly incompetent for the charges they have received. Regulations and rules have been rolled back across the board from education to transportation and healthcare. He even left the US Postal Service, the oldest existing federal agency, out of the massive public financing package addressing the economic effects of the pandemic. This is symbolic of the entire attitude to the utility, or from the antifederalist perspective, the futility, of the federal government.

Crucially in the context of the COVID-19 pandemic, the federal pandemic warning system was dismantled as a leftover from Obama; the CDC, the main federal government agency charged with preparing for and managing disease outbreaks, had its budget gutted; and Trump has left the states and their governors to fend for themselves without much of any real federal policy or plan to speak of (Haffajee and Mello, 2020). Simultaneously, Trump has also exhibited a complete disinterest in collaborating with other countries, including longtime allies, in addressing the pandemic. This would be to resurrect the dreadful global international order that he has consistently decried. He has attacked and raised the possibility of 
removing US funding from the World Health Organization as if it were to blame for his own months long passivity.

Repeatedly, Trump also has returned to the populist idea that the pandemic was the product of travelers, particularly foreign ones, rather than that once present within the country it is tracing and isolating people (as in "community spread") who test positive that should take center stage rather than simply restricting international travel. Returning to his obsession with immigrants, he obscured his mismanagement of the pandemic by announcing a total ban on immigration as if immigrants were the continuing source of infection rather than Americans' own conationals and a threat to "jobs" once the pandemic was over (NY Times, 2020). Yet as time went by the federal government seemed less rather than more effective in testing for the virus (Lim, 2020). The states were left carrying the can, so to speak. Finally, in his daily press conferences Trump has found a substitute for the frequent rallies that characterized both his 2016 campaign and his period in office where he rambles on incoherently, accuses hospital staff of pilfering face masks and other Personal Protective Equipment, contradicts the public health experts, peddles his own doubtful cures like a snake-oil salesman, and instead of showing any grasp of the managerial issues facing his government, verbally assaults the media representatives present and dispenses advice that is the opposite of that he has given the day before (e.g. Wright and Campbell, 2020; Rucker and Costa, 2020; Lipton et al., 2020).

In the end, therefore, Trump's angry incompetence is best framed in terms of a longstanding set of ideological-institutional trends in the US that have systematically weakened the role of the federal government and thus laid the groundwork for the failures manifest in the US response to the COVID-19 pandemic of 2020. Trump has no idea that his rhetoric about walling out the world cannot obscure the real walls within the country that the COVID-19 virus has exposed. In this context his national-populism could only ever be a fake version of the real thing.

\section{References}

Agnew, J. (2005). Hegemony: The New Shape of Global Power. Philadelphia: Temple University Press.

Agnew, J., and Shin, M. (2019). Mapping Populism: Taking Politics to the People. Lanham MD: Rowman and Littlefield.

Baker, P. (2020). Trump proceeds with post-Impeachment purge amid pandemic. New York Times, 4 April.

Bergen, P. (2019). Trump and his Generals: The Cost of Chaos. New York: Penguin.

Brown, W. (2019). In the Ruins of Neoliberalism: The Rise of Antidemocratic Politics in the West. New York: Columbia University Press.

Bump, P. (2020). The circumstances are wildly different, Trump's response is the same. Washington Post, 5 April.

Drezner, D. (2020). Promises made, promises broken: will it matter? Washington Post, 14 April.

Edling, M. M. (2003). A Revolution in Favor of Government: Origins of the US Constitution and the Making of the American State. New York: Oxford University Press. 
Frank, T. (2008). The Wrecking Crew: How Conservatives Ruined Government, Enriched Themselves, and Beggared the Nation. New York: Holt.

Gabriel, T., and Lerer, L. (2020). Who are the voters behind Trump's higher approval rating? New York Times, 31 March.

Gerson, M. (2020). The dangerous conservative campaign against expertise. Washington Post, 9 April.

Glasser, S. B. (2020). A President unequal to the moment. New Yorker, 12 March.

Haffajee, R. L., and Mello, M. M (2020). Thinking globally, acting locally - the US response to Covid-19. New England Journal of Medicine, 2 April.

Ketcham, R. (Ed.). (1986). The Anti-Federalist Papers and the Constitutional Convention Debates. New York: New American Library.

Kilgore, E. (2020). Red America may blame Blue America for Coronavirus. New York Magazine, 20 March.

Lim, D. (2020). Coronavirus testing hits dramatic slowdown in US. Politico, 14 April.

Lipton, E. et al. (2020). He could have seen what was coming: behind Trump's failure on the virus. New York Times, 11 April.

Maxwell, A., and Shields, T. (2019). The Long Southern Strategy: How Chasing White Voters in the South Changed American Politics. New York: Oxford University Press.

NY Times (2020). Trump says he will stop immigration. New York Times, 21 April.

Packer, G. (2020). Underlying conditions: We are living in a failed state. The Atlantic, June.

Parker, A., and Rucker, P. (2020). How Trump's attempts to win the daily news cycle feed a chaotic Coronavirus response. Washington Post, 4 April.

Peel, P. (2018). The populist theory of the state in early American political thought, Political Research Quarterly, 71(1), 115-26.

Riley, D. (2017). American Brumaire? New Left Review, (103), 21-32.

Rucker, P., and Leonnig, C. (2020). A Very Stable Genius: Donald J. Trump's Testing of America. New York: Penguin.

Rucker, P., and Costa, R. (2020). Commander of confusion: Trump sows uncertainty and seeks to cast blame in Coronavirus crisis. Washington Post, 2 April.

Thornhill, J. (2018). How to fix Facebook. Financial Times, 6 August.

Waldmeir, P. (2020). Trump's support rallies round his flag in the Midwest. Financial Times, 7 April.

Wehner, P. (2020). The party of the aggrieved. The Atlantic, 21 April.

Wright, T., and Campbell, K. (2020). The Coronavirus is exposing the limits of populism. The Atlantic, 4 March. 